Creative commons User License: CC BY-NC-ND

Abstracted by: EBSCOhost, Electronic Journals Service (EJS), Google Scholar, Directory of Open Access Journals (DOAJ), Journal Seek, Scientific Commons,

Food and Agricultural Organization (FAO), CABI and Scopus
Journal of Agricultural Extension

Vol. 21 (1) February, 2017

ISSN(e): 24086851; ISSN(Print); 1119944X

http://journal.aesonnigeria.org

http://www.ajol.info/index.php/jae

Email: editorinchief@aesonnigeria.org

\title{
Utilization of Agro-meteorological Services among Arable Crop Farmers in Oyo State, Nigeria \\ http://dx.doi.org/10.4314/jae.v21i1.5
}

\section{Thomas, K.A}

Department of Agricultural Extension and Rural Development, University of Ibadan, Ibadan, Nigeria

Email: kehindeadesina@yahoo.com; ka.thomas@uimail.edu.ng

Telephone Number: +2348055951145

\section{Sanyaolu, A.S}

Department of Agricultural Extension and Rural Development, University of Ibadan, Ibadan, Nigeria

Email: sanyaolusaheed56@gmail.com

Telephone Number: +2348067023050

\section{Abstract}

The study assessed arable crop farmers' utilization of agro-meteorological services in Oyo State, Nigeria. Multi-stage sampling procedure was employed for this study. Oyo State was stratified into rainforest and savannah. One local government each was randomly selected from each of the vegetation zones, which were Iddo and Ogbomoso north. List of arable crop farmers was obtained from the selected LGAs from where $02 \%$ and $03 \%$ of the population were randomly selected to give a total sample size of 167 respondents. Data were presented with descriptive and analysed inferential statistical tools: Chisquare and PPMC. The results reveal that the majority of respondents were males (83.6\%), Christians (62.5\%) and had formal education (79.0\%). About $36.2 \%$ were between 50 and 59 years and $65.8 \%$ had a farm size of $1-5$ acres. Maize and cassava were the most cultivated crops, Oyo State Agricultural Development Programme (OYSADEP) was the only communication channel used. More than half (66.4\%) of the farmers were aware of seasonal rainfall prediction, untimely access to information was the most severe constraint (1.23) and the used of agro-meteorological service was slightly above average (54.6\%). Farm size $(r=0.162)$ and family size $(r=0.309: \quad p \leq 0.05)$ were significantly related to utilization of agrometeorological services. The scale of agro-meteorological service utilisation requires deliberate agro-meteorological extension education services and timely delivery of agro-meteorological information to farmers.

Keywords: Agro-meteorological services, meteorological information utilization, Arable crop farmers 
Creative commons User License: CC BY-NC-ND

Abstracted by: EBSCOhost, Electronic Journals Service (EJS), Google Scholar, Directory of Open Access Journals (DOAJ),

Journal Seek, Scientific Commons,

Food and Agricultural Organization (FAO), CABI and Scopus
Journal of Agricultural Extension

Vol. 21 (1) February, 2017

ISSN(e): 24086851; ISSN(Print); 1119944X

http://journal.aesonnigeria.org

http://www.ajol.info/index.php/jae

Email: editorinchief@aesonnigeria.org

\section{Introduction}

The agricultural sector contributes some percentage of the Nigerian Gross National Product and the majority of the rural populace are employed in this sector. The dominant role of agriculture makes it obvious that even minor climate deteriorations can cause devastating socioeconomic consequences. The Intergovernmental Panel on Climate Change, IPCC's Fourth Assessment Report summary for Africa describes a trend of warming at a rate faster than the global average, and increasing aridity in many countries. Climate change exerts multiple stresses on the biophysical as well as the social and institutional environments that underpin agricultural production (IPCC, 2007).

Effect of climate change on agriculture is evidenced by attendant consequences on the environmental and socio-economic life of the rural dwellers whose primary occupation is farming. According to Khanal (2009), the patterns of impact of climate change on agriculture can be classified into biophysical and socio-economic impact. The biophysical impacts include; physiological effects on crop and livestock, change in land, soil and water resources, increased weed and pest challenges, shifts in spatial and temporal distribution of impacts, sea level rise and changes to ocean salinity and sea temperature rise causing fish to inhabit in different ranges. The socioeconomic impacts result in decline in yield and production, reduced marginal GDP from agriculture, fluctuation in world market price, changes in geographical distribution of trade regime, increased number of people at risk of hunger and food insecurity, migration and civil unrest. Corroborating this submission, Van der Zaag (2010) opined that grain yields have remained stagnant in Africa because of high temporal variability and inconsistency in rainfall pattern which is evident in 2012 when many, maize, rice, yam and cassava farms were flooded in Kogi, Edo, Adamawa and Oyo States. In the same vein, Akinbile (2010) affirmed that the estimate of the effects of climate change on crop yields is predominantly negative for the tropics. 
Creative commons User License: CC BY-NC-ND

Abstracted by: EBSCOhost, Electronic Journals Service (EJS), Google Scholar, Directory of Open Access Journals (DOAJ),

Journal Seek, Scientific Commons,

Food and Agricultural Organization (FAO), CABI and Scopus
Journal of Agricultural Extension

Vol. 21 (1) February, 2017

ISSN(e): 24086851; ISSN(Print); 1119944X

http://journal.aesonnigeria.org

http://www.ajol.info/index.php/jae

Email: editorinchief@aesonnigeria.org

As global warming accelerates, it is expected that agricultural adaptation to climate change can only be meaningful, if irrigated agriculture gains prominence. Unfortunately, agricultural practice in Nigeria is still predominantly rain-fed and therefore particularly vulnerable to the impacts of climate change as noted before (FAO, 2008; Medugu, 2008 and IFAD, 2007). The consequences are that the increasing frequency and severity of droughts are likely to cause: crop failure; high and rising food prices; distress sale of animals; de-capitalization, impoverishment, hunger, and eventually famine. Households will probably try to cope with their cash and food shortage by cutting and selling more firewood, thereby exacerbating land degradation and accelerating the onset of desertification, and by moving temporarily or permanently to more favoured areas. In line with this projection, Medugu (2009) stated that Nigeria is one of the countries expected to be most affected by the impacts of climate change through sea level rise along her coast line, intensified desertification, erosion and flooding disasters and general land degradation.

Nigeria is experiencing adverse climate conditions with negative impacts on the welfare of millions of people. Seasonal variations, unpredictability and unreliability rainfall pattern in the dry sub- humid and semi- arid ecological zones. Persistent droughts and flooding, off-season rains and dry spells have sent growing seasons out of place. One of the adaptation measures as a response to this tide is the establishment of Nigeria Meteorological Agency (NIMET). The main objective involves providing weather, climate and water information for sustainable development and safety. However, its mandates include: ensuring that international best standards practices are maintained in all areas of meteorology including agriculture, promote the services of meteorology in agriculture, drought and desertification activities, prediction of early season weather storm, rainfall predictions, wind dimension, sensitizing the farmers on the warnings and predictions, organizing workshops for farmers' groups. 
Creative commons User License: CC BY-NC-ND

Abstracted by: EBSCOhost, Electronic Journals Service (EJS), Google Scholar, Directory of Open Access Journals (DOAJ), Journal Seek, Scientific Commons,

Food and Agricultural Organization (FAO), CABI and Scopus
Journal of Agricultural Extension

Vol. 21 (1) February, 2017

ISSN(e): 24086851; ISSN(Print); 1119944X

http://journal.aesonnigeria.org

http://www.ajol.info/index.php/jae

Email: editorinchief@aesonnigeria.org

Several studies have established the effects of climate change on agricultural production and adaptation strategies required to boost agriculture in Nigeria. Adebisi-Adelani (2013) investigated farmers' perception of the effect of climate change in production of citrus and tomatoes in Nigeria, Onyegbula (2015) chronicled the climatic change adaptation strategies of rice farmers in Nigeria, and Tella (2016) examined the livelihood analysis and coping strategies of rural women to climate change in North-eastern Nigeria among others. However, the utilisation of Nigeria Meteorological Agency (NIMET) services as a measure to climate change adaptation among arable crop farmers has not been adequately assessed. It is against this backdrop that the study asked the following questions:

i. what are the socio-economic characteristics of the respondents in the study area?

ii. what are the available agro-meteorological services NIMET renders?

iii. do farmers have access to these agro-meteorological services?

iv. what is the extent of use of the agro-meteorological services by farmers?

v. what are the constraints faced by farmers towards the use of these services?

\section{Objectives of the study}

The specific objectives were to:

i. ascertain the socio-economic characteristics of the respondents in the study area

ii. examine the available agro-meteorological services NIMET renders

iii. determine access to these agro-meteorological services

iv. describe extent of use of the agro-meteorological services by farmers

v. investigate the constraints faced by farmers towards the use of these services 
Creative commons User License: CC BY-NC-ND

Abstracted by: EBSCOhost, Electronic Journals Service (EJS), Google Scholar, Directory of Open Access Journals (DOAJ),

Journal Seek, Scientific Commons,

Food and Agricultural Organization (FAO), CABI and Scopus
Journal of Agricultural Extension

Vol. 21 (1) February, 2017

ISSN(e): 24086851; ISSN(Print); 1119944X

http://journal.aesonnigeria.org

http://www.ajol.info/index.php/jae

Email: editorinchief@aesonnigeria.org

\section{Methodology}

\section{Area of Study}

The study was carried out in Oyo State, which is geographically located in the South West region of Nigeria between latitude $7^{\circ} 02^{1} \mathrm{~N}$ and $9^{0} 10^{1}$ and longitude $2^{0} 04^{1} \mathrm{E}$ and $4030^{1} \mathrm{E}$. It covers approximately an area of 28,454 square kilometres. The state has a population of $5,591,589$, consisting of $2,809,840$ males and 2,781,749 females (NPC, 2006). It is bounded in the South by Ogun State, in the North by Kwara State, in the West; it is partly bounded by Ogun State and partly by the republic of Benin, while in the East by Osun State. The climate is equatorial with distinct wet (rainy) and dry seasons with relatively high humidity. The dry season lasts from November to March while the wet season starts from April and ends in October. The mean annual rainfall is $1480 \mathrm{~mm}$ with a mean monthly temperature range of $18-24^{\circ} \mathrm{C}$ during the rainy season and $30-35^{\circ} \mathrm{C}$ during the dry season. The climate in the state favours the cultivation of crops like maize, yam, cassava, millet, rice, plantain, cocoa, kolanut, coffee, oil palm, cashew etc. The state has witnessed frequency of weather variability manifested as continuous rise in surface temperature, cloud cover, humidity and rainfall. This is substantiated in the red alert issued by NIMET in 2016, which classified Oyo State as one of the 11 states prone to flood due to meteorological report that predicted high volume of rainfall in the designated states. (http://www.thisdaylive.com/index.php/2016/08/08/11).

\section{Population and sampling procedure}

The population of the study constitutes all arable crop farmers and NIMET zonal director in Oyo State. Multi-stage sampling procedure was employed for this study. The 33 Local Government Areas (LGAs) in Oyo State was stratified into rainforest and savannah vegetation zones. Simple random sampling technique was used to select Iddo and Ogbomoso north LGAs from rainforest 
Creative commons User License: CC BY-NC-ND

Abstracted by: EBSCOhost, Electronic Journals Service (EJS), Google Scholar, Directory of Open Access Journals (DOAJ), Journal Seek, Scientific Commons,

Food and Agricultural Organization (FAO), CABI and Scopus
Journal of Agricultural Extension

Vol. 21 (1) February, 2017

ISSN(e): 24086851; ISSN(Print); 1119944X

http://journal.aesonnigeria.org

http://www.ajol.info/index.php/jae

Email: editorinchief@aesonnigeria.org

and savannah vegetation zones respectively. List of arable crop farmers was obtained from the selected LGAs and proportionate sampling technique was used to select $02 \%$ and $03 \%$ of the population to give a total sample size of 167 respondents out of which 152 were analysable.

\section{Method of data collection}

Both quantitative and qualitative methods were used. Quantitative data were elicited through questionnaire, while the quantitative data was obtained through in-depth interview with NIMET zonal director.

\section{Measurement of variables}

\section{Independent variables}

i. Socio-economic characteristics: These include sex, religion, marital status, ethnic background, family size, farm size, types of crops grown age, level of education. These were measured in nominal and ordinal level of measurement.

ii. Access to agro-meteorological services: Parameters measured include: rainfall and temperature prediction, synoptic weather forecast, soil moisture indices, potential evapo-transpiration, growing degree days, crop stages, daily weather forecasts, short range weather forecast, sensitization on the services, organising workshops, and drought prediction. Respondents were asked to tick access to the services on the scale of accessible $=1$ and not accessible $=0$. The maximum obtainable score was 12 , while the minimum was zero. The mean score was determined and used as a benchmark for categorisation for access to agro-meteorological services.

iii. Constraints to agro-meteorological service utilization. Respondents reacted to eight constraints items measured on the scale of not a constraint $=0$, mild constraint $=1$, serious constraint $=2$. The mean scores were obtained and ranked to determine the level of constraints to agrometeorological service utilization. 
Creative commons User License: CC BY-NC-ND

Abstracted by: EBSCOhost, Electronic Journals Service (EJS), Google Scholar, Directory of Open Access Journals (DOAJ),

Journal Seek, Scientific Commons,

Food and Agricultural Organization (FAO), CABI and Scopus
Journal of Agricultural Extension

Vol. 21 (1) February, 2017

ISSN(e): 24086851; ISSN(Print); 1119944X

http://journal.aesonnigeria.org

http://www.ajol.info/index.php/jae

Email: editorinchief@aesonnigeria.org

\section{Dependent variable}

The dependent variable for this study was utilization. Respondents were asked to tick use $=1$, not use $=0$ to the twelve items provided. Adding all responses together derived Index of use of agro-meteorological services and the mean index was computed. Those whose indices were between the mean $(5 \pm 1)$ and the maximum were categorised as high while those below the mean were categorised as low levels of use of agro-meteorological services.

\section{Results and Discussion}

\section{Respondents' Socio-economic Characteristics}

Age: respondents' age distribution in Table 1 shows that $36.2 \%$ were between 50-59 years age range. This implies that the farming population is ageing. On the contrary, Ekong (2003) posited that Nigerian farmers were between 45 to 50 years of age. Nonetheless, the age is a function of experience needed for farm production business and adaptation response required in any intervention programmes on crop production. It can also elicit issues that bother on transfer and adoption of agricultural innovations and technologies

Sex: The result shows that the majority $(83.6 \%)$ of the respondents were male.. Culturally, men are usually involved in agricultural practices in the south-western part of Nigeria due to access to productive resources. This is corroborated in the submission of Nwanebo (2012). He opined that lack of access to productive resources such as land; credit, agricultural inputs and extension services are factors affecting the contribution of women in agriculture. It could therefore be deduced that, man's opinion is germane to the issues related to climate change and agro-meteorological services utilisation. 
Creative commons User License: CC BY-NC-ND

Abstracted by: EBSCOhost, Electronic Journals Service (EJS), Google Scholar, Directory of Open Access Journals (DOAJ),

Journal Seek, Scientific Commons,

Food and Agricultural Organization (FAO), CABI and Scopus
Journal of Agricultural Extension

Vol. 21 (1) February, 2017

ISSN(e): 24086851; ISSN(Print); 1119944X

http://journal.aesonnigeria.org

http://www.ajol.info/index.php/jae

Email: editorinchief@aesonnigeria.org

Religion: Table 1 further shows that the majority (62.5\%) were Christians, Muslims (34.9\%) and $2.6 \%$ practice traditional religion. The presence of various religious fates among arable crop farmers implies that there might not be discrimination against agro-meteorological services utilisation. Religion is a major consideration for adoption of any technology. In line with this position, Olajide-Taiwo (2015) confirmed that any innovation practice must be in line with farmer's religious background in order to facilitate utilisation.

Educational level: The study reveals that substantive number $(79.0 \%)$ had one form of education or the other. About $30.9 \%$ had secondary education, tertiary $(25.7 \%)$, primary (17.8\%), adult education (4.6\%) and non-formal education (21.0\%). Oladeji (2011) and Ann et al., (2013) corroborated this finding. They confirmed that the majority of farmers in South-western Nigeria had one form of educational qualification or the other. This implies that, educational attainment could enhance effective training, access to agricultural information and use of agricultural information.

Monthly income: Most (70.5\%) realised income of about N21, 000 - N30, 000 monthly. It implies that ability to commit money to obtain information might be low. Invariably, they may not be favourably disposed to taking risks in trying new agricultural innovations like the agro-meteorological services to ameliorate the effect of climate change. This is in consonance with Arimi (2015) who asserted that farmers 'income might affect technology utilisation because low-income farmers may find it difficult to invest on technology that will enhance farm productivity.

Family size: Table 1 further shows that the majority (47.4\%) had between 6-8 family sizes. It is suggestive that large family size is prevalent among rural households. Orire, (2000) who quoted Ekong (2003) opined that, in societies where little mechanisation is carried out, the greater the number of hands (labour) available, the greater the productivity of the family. 
Creative commons User License: CC BY-NC-ND

Abstracted by: EBSCOhost, Electronic Journals Service (EJS), Google Scholar, Directory of Open Access Journals (DOAJ), Journal Seek, Scientific Commons,

Food and Agricultural Organization (FAO), CABI and Scopus
Journal of Agricultural Extension

Vol. 21 (1) February, 2017

ISSN(e): 24086851; ISSN(Print); 1119944X

http://journal.aesonnigeria.org

http://www.ajol.info/index.php/jae

Email: editorinchief@aesonnigeria.org

Farm size: The study shows that the majority (65.8\%) had between 1-5 acres of land. This implies that most of the crop farmers were small-scale farmers. Spencer (1990) and Agbongiarhuoyi, et al (2013) affirmed that the upper limit of small-scale farming is 3ha ad 2.5ha respectively. It indicates therefore that, utilisation of new technology will be low. This implies that information gathering is less worthwhile for small-scale farmers as large farm size enable farmers to practice different climate change adaptation strategies. This is in agreement with Maddison (2007) who opined that adaptation has fixed cost element. 
Creative commons User License: CC BY-NC-ND

Abstracted by: EBSCOhost, Electronic Journals Service (EJS), Google Scholar, Directory of Open Access Journals (DOAJ), Journal Seek, Scientific Commons,

Food and Agricultural Organization (FAO), CABI and Scopus
Journal of Agricultural Extension

Vol. 21 (1) February, 2017

ISSN(e): 24086851; ISSN(Print); 1119944X

http://journal.aesonnigeria.org

http://www.ajol.info/index.php/jae

Email: editorinchief@aesonnigeria.org

Table 1: Respondents' percentage distribution by socio-economic characteristics

\begin{tabular}{|l|l|l|}
\hline Variables & Percentage & Mean \\
\hline Age & & \\
\hline $30-39$ & 13.2 & \\
\hline $40-49$ & 27.6 & $50.7 \pm 9.7$ \\
\hline $50-59$ & 36.2 & \\
\hline $60-69$ & 19.7 & \\
\hline $70-79$ & 3.3 & \\
\hline Sex & & \\
\hline Male & 83.6 & \\
\hline Female & 15.8 & \\
\hline Religion & & \\
\hline Islam & 34.9 & \\
\hline Christianity & 62.5 & \\
\hline Traditional & 2.7 & \\
\hline Educational level & & $2.3 \pm 1.4$ \\
\hline No formal education & 21 & \\
\hline Adult education & 4.6 & \\
\hline Primary & 17.8 & \\
\hline Secondary & 30.9 & \\
\hline Tertiary & 25.7 & \\
\hline Family size & & \\
\hline $3-5$ & 39.5 & \\
\hline $6-8$ & 47.4 & \\
\hline $9-26$ & 13.1 & \\
\hline Farm size/acre & & \\
\hline $1-5$ & 65.8 & \\
\hline $6-10$ & 27.6 & \\
\hline $11-15$ & 3.3 & \\
\hline $16-25$ & 3.3 & \\
\hline & & \\
\hline
\end{tabular}


Creative commons User License: CC BY-NC-ND

Abstracted by: EBSCOhost, Electronic Journals Service (EJS),

Google Scholar, Directory of Open Access Journals (DOAJ),

Journal Seek, Scientific Commons,

Food and Agricultural Organization (FAO), CABI and Scopus
Journal of Agricultural Extension

Vol. 21 (1) February, 2017

ISSN(e): 24086851; ISSN(Print); 1119944X

http://journal.aesonnigeria.org

http://www.ajol.info/index.php/jae

Email: editorinchief@aesonnigeria.org

\begin{tabular}{|l|l|l|}
\hline Estimated Monthly Income (N) & & \\
\hline Less than 10,000 & 2.6 & $26,400 \pm 6,700$ \\
$11,000-20,000$ & 0.0 & \\
$21,000-30,000$ & 70.5 & \\
$31,000-40,000$ & 7.9 & \\
$41,000-50,000$ & 11.2 & \\
More than 50,000 & 7.2 & \\
\hline
\end{tabular}

\section{Availability of Agro-meteorological Services}

Table 2 shows that the majority $(75.7 \%)$ claimed that NIMET made information on seasonal rainfall prediction available, more than half (56.6\%) opined that information on crop stages performance is disseminated from NIMET. On daily weather forecast, slightly below half (49.3\%) affirmed that such messages get to them, while very few (25.7\%) confirmed getting information on wind direction from the agency.

Few $(36.8 \%)$ agreed that NIMET provides information on soil moisture indices. On general weather situation, the majority (61.8\%) attested to the fact that NIMET provides such information. It implies therefore that farmers take cognisance of the change in the elements of general weather situation like rainfall parameters, sunshine, temperature etc. However, less than half $(40.8 \%)$ was of the opinion that NIMET sensitize and organise training workshop on climate change. About 32\% claimed that NIMET made information on drought prediction available. Nonetheless, NIMET (2012) asserted that over half of the earth is susceptible to drought every year.

Results on flood prediction on Table 2 indicate that $40.8 \%$ confirmed availability of information on drought prediction despite the havoc wrecked by 2012-flood disaster in Oyo State. Furthermore, less than half $(42.8 \%)$ said that information on drought prediction is not feasible. Few (16.4\%) claimed that NIMET renders information on drought prediction. On the whole, availability of agro-meteorological services is low even when farmers claimed to have knowledge of changes in climate parameters. Roudier, et al. (2014) corroborates this submission; they opined that farmers in Nigeria are aware of 
Creative commons User License: CC BY-NC-ND

Abstracted by: EBSCOhost, Electronic Journals Service (EJS), Google Scholar, Directory of Open Access Journals (DOAJ), Journal Seek, Scientific Commons,

Food and Agricultural Organization (FAO), CABI and Scopus
Journal of Agricultural Extension

Vol. 21 (1) February, 2017

ISSN(e): 24086851; ISSN(Print); 1119944X

http://journal.aesonnigeria.org

http://www.ajol.info/index.php/jae

Email: editorinchief@aesonnigeria.org

climate change, which is manifested in changes in rainfall intensity and distribution, increase in temperature and declining soil fertility.

Table 2: Percentage distribution of respondents based on availability of agro-meteorological services

\begin{tabular}{ll}
\hline Agro-meteorological services & Percentages \\
\hline Seasonal rainfall prediction & 75.7 \\
Information on crop stages performance & 56.6 \\
Daily weather forecast & 49.3 \\
Wind direction & 25.7 \\
Soil moisture indices & 36.8 \\
General weather situation & 61.8 \\
Sensitization and training workshop on climate & 40.8 \\
change & \\
Drought prediction & 32.2 \\
Potential flood prediction & 40.8 \\
Early warning messages and preparedness & 42.8 \\
attempt & \\
Climate field school & 16.4 \\
\hline
\end{tabular}

\section{Communication channels used to disseminate agro-meteorological services}

Table 3 indicates that half $(50 \%)$ of the respondents always receive agrometeorological information from extension agents of Oyo State Agricultural Development Agency compared to other sources. It is suggestive that agrometeorological information was largely disseminated through the extension agents of Oyo State Agricultural Development Project (OYSADEP). Agricultural Project Monitoring and Evaluation Unit (1997) indicated that extension agents strongly and positively related the adoption of improved technologies to the frequency of visits. It follows therefore that; frequent extension contact will help to enhance technical competence on agrometeorological services required for climate change adaptation. Adebayo, 
Creative commons User License: CC BY-NC-ND

Abstracted by: EBSCOhost, Electronic Journals Service (EJS),

Google Scholar, Directory of Open Access Journals (DOAJ),

Journal Seek, Scientific Commons,

Food and Agricultural Organization (FAO), CABI and Scopus
Journal of Agricultural Extension

Vol. 21 (1) February, 2017

ISSN(e): 24086851; ISSN(Print); 1119944X

http://journal.aesonnigeria.org

http://www.ajol.info/index.php/jae

Email: editorinchief@aesonnigeria.org

Onu, Adebayo and Anyanwu (2012) affirmed that constant extension contact could elicit adoption of technology.

Table 3: Channels of communication used to disseminate agrometeorological services

\begin{tabular}{llll}
\hline Information Sources & $\begin{array}{l}\text { Never } \\
(\%)\end{array}$ & $\begin{array}{l}\text { Occasionally } \\
(\%)\end{array}$ & Always (\%) \\
\hline OYSADEP & 20.4 & 29.6 & 50.0 \\
Farmers/Friend & 17.8 & 36.2 & 46.1 \\
Radio & 13.2 & 38.8 & 48.0 \\
Television & 21.7 & 49.3 & 30.0 \\
Newspaper & 55.3 & 30.9 & 13.8 \\
Internet & 81.6 & 12.5 & 5.9 \\
\hline
\end{tabular}

\section{Accessibility to Agro-meteorological Services}

Table 4 shows that more than half $(59.9 \%)$ have access to seasonal rainfall prediction, half $(50 \%)$ were able to access information on crop stages and less than half $(41.4 \%)$ could access daily weather forecast information from NIMET. Furthermore, few (19.1\%) have access to information on wind direction (28.9\%) and have access soil moisture indices. However, more than half $(57.2 \%)$ claimed access to general weather situation, while about $32.2 \%$ affirmed access to sensitization and training workshop and agrometeorological services. Access to drought (28.3\%) and flood (35.5\%) prediction services was low. It could be deduced that respondents' access to meteorological services was generally low. It implies that timely response and adaptation strategies required of arable crop farmers to cope with the climate change effects will not be in place. This has serious implication on food 
Creative commons User License: CC BY-NC-ND

Abstracted by: EBSCOhost, Electronic Journals Service (EJS),

Google Scholar, Directory of Open Access Journals (DOAJ),

Journal Seek, Scientific Commons,

Food and Agricultural Organization (FAO), CABI and Scopus
Journal of Agricultural Extension

Vol. 21 (1) February, 2017

ISSN(e): 24086851; ISSN(Print); 1119944X

http://journal.aesonnigeria.org

http://www.ajol.info/index.php/jae

Email: editorinchief@aesonnigeria.org

security by reducing crop yields, which in turn increase the price of food thereby forcing people to change production and consumption patterns (European Commission, 2009).

Table 4: Distribution of respondents based on access to agrometeorological services

\begin{tabular}{ll}
\hline Agro meteorological Services & Accessible (\%) \\
\hline Seasonal rainfall prediction & 59.9 \\
Information on crop stages performance & 50.0 \\
Daily weather forecast & 41.4 \\
Wind direction & 19.1 \\
Soil moisture indices & 28.9 \\
General weather situation & 57.2 \\
Sensitization and training workshop on & 32.2 \\
Climate change & \\
Drought prediction & 28.3 \\
Potential flood prediction & 35.5 \\
Early warning messages and preparedness & 38.2 \\
attempt & \\
Climate field school & 17.1 \\
\hline
\end{tabular}

\section{Constraints to Agro-meteorological Services Utilization}

Untimely (1.23 \pm 082$)$ information on agro-meteorological services is the major constraints to its utilisation (Table 5).. Timely availability, accessibility, adequate and effective information on climate change is pivotal to planning in agricultural enterprise. Consequently, farmers are better guided on appropriate adaptation strategies. Corroborating this finding, Anselm and Taofeeq (2010) asserted that information on climate change is imperative for climate change adaptation.

Table 5: Respondents' distribution based on constraints to agrometeorological services utilization

\begin{tabular}{lllll}
\hline & Constraints & Mean & SD & Rank \\
\hline 1. & Lack of access to internet & 1.12 & 0.71 & $4^{\text {th }}$ \\
2. & Lack of accurate agro-meteorological & 1.17 & 0.68 & $3^{\text {rd }}$ \\
\hline
\end{tabular}


Creative commons User License: CC BY-NC-ND

Abstracted by: EBSCOhost, Electronic Journals Service (EJS), Google Scholar, Directory of Open Access Journals (DOAJ), Journal Seek, Scientific Commons,

Food and Agricultural Organization (FAO), CABI and Scopus
Journal of Agricultural Extension

Vol. 21 (1) February, 2017

ISSN(e): 24086851; ISSN(Print); 1119944X

http://journal.aesonnigeria.org

http://www.ajol.info/index.php/jae

Email: editorinchief@aesonnigeria.org

\begin{tabular}{llll}
\hline & information & & \\
3. Information is too technical to apply & 0.90 & 0.42 & $5^{\text {th }}$ \\
4. Inability to read and write & 0.78 & 0.31 & $7^{\text {th }}$ \\
5. Irrelevant information & 0.71 & 0.41 & $8^{\text {th }}$ \\
6. Information is not timely & 1.23 & 0.82 & $1^{\text {st }}$ \\
7. Information is too expensive to access & 1.20 & 0.61 & $2^{\text {nd }}$ \\
8. Usage of service is time consuming & 0.82 & 0.21 & $6^{\text {th }}$ \\
\hline
\end{tabular}

\section{Agro-meteorological Services Utilization}

The result on Table 6 shows that the majority $(71.1 \%)$ utilised information on seasonal rainfall prediction, 59.2\% claimed to utilised information on crop stages and $39.5 \%$ utilise daily weather forecast agrometeorological services. Furthermore, less than half (35.0\%), (41.4\%), (40.8\%), (30.3\%), (30.3\%), (41.4\%), (40.1\%), (22.4\%) utilised information on wind direction, soil moisture, general weather condition, sensitization and training workshop, drought prediction, potential flood prediction, early warning messages and preparedness attempt and climate field school respectively. The implication from the finding is that, the meteorological services has not been fully utilised probably because of the associated constraints related to untimely dissemination of the information by the agency (Table 5). AsensoOkyere and Davis (2009) in a related study agreed that knowledge acquisition could only translate to functional change if shared and utilised.

Table 6: Percentage distribution of respondents based on agrometeorological services utilization

\begin{tabular}{ll}
\hline Agro-meteorological Services & Use \\
\hline Seasonal rainfall prediction & $\%$ \\
Information on crop stages & 71.1 \\
Daily weather forecast & 59.2 \\
Wind direction & 39.5 \\
Soil moisture indices & 25.0 \\
General weather situation & 41.4 \\
Sensitization and training workshop & 59.2 \\
on climate change & 30.3 \\
Drought prediction & 30.3 \\
Potential flood prediction & 41.4
\end{tabular}


Creative commons User License: CC BY-NC-ND

Abstracted by: EBSCOhost, Electronic Journals Service (EJS),

Google Scholar, Directory of Open Access Journals (DOAJ),

Journal Seek, Scientific Commons,

Food and Agricultural Organization (FAO), CABI and Scopus
Journal of Agricultural Extension

Vol. 21 (1) February, 2017

ISSN(e): 24086851; ISSN(Print); 1119944X

http://journal.aesonnigeria.org

http://www.ajol.info/index.php/jae

Email: editorinchief@aesonnigeria.org

Early warning messages and

40.1

preparedness attempt

Climate field school

22.4

\section{Relationship Between Selected Respondents' Socio-economic Characteristics and Utilization of Agro-meteorological Services.}

Family size $(r=0.309: p \leq 0.05)$ and farm size $(r=0.162: p \leq 0.05)$ had significant relationship with utilization of agro-meteorological services (Table 7). However, educational level $\left(x^{2}=7.281\right.$ : $\left.p \geq 0.05\right)$, religion $\left(x^{2}=1.380\right.$ : $\left.p \geq 0.05\right)$ and age $(r=-0.13: p \geq 0.05)$ were not significantly related to utilization of agrometeorological service. The implication is that farming households with large family size tend to have more labour available for agricultural enterprise, while larger farm holding will encourage seeking information on agro-meteorological services to minimise losses associated with the effect of climate change. In line with this submission, IPCC (2012) opined that knowledge generated on climate change adaptation would elicit decision making, livelihood diversification and risk management.

Table 7: Relationship between selected respondents' socio-economic characteristics and utilization of agro-meteorological service

\begin{tabular}{lllll}
\hline Variable & $x^{2}$ & Df & $\begin{array}{l}\text { Contingency } \\
\text { coefficient }\end{array}$ & r-value \\
\hline Religion & 1.380 & 3 & 0.095 & \\
Educational level & 7.281 & 4 & 0.214 & -0.13 \\
Age & & & & $0.309^{*}$ \\
Family size & & & & 0.162 \\
Farm size & & & &
\end{tabular}

${ }^{*} \mathrm{P} \leq 0.05$ 
Creative commons User License: CC BY-NC-ND

Abstracted by: EBSCOhost, Electronic Journals Service (EJS), Google Scholar, Directory of Open Access Journals (DOAJ), Journal Seek, Scientific Commons,

Food and Agricultural Organization (FAO), CABI and Scopus
Journal of Agricultural Extension

Vol. 21 (1) February, 2017

ISSN(e): 24086851; ISSN(Print); 1119944X

http://journal.aesonnigeria.org

http://www.ajol.info/index.php/jae

Email: editorinchief@aesonnigeria.org

\section{Relationship Between Constraints to Agro-meteorological Services Utilisation and Utilization of Agro-meteorological Services}

There exists significant relationship between constraint and utilization of agrometeorological (Table 8). It implies that constraint encountered by the respondent influenced their level of utilization. Therefore, the more constraint encountered by the respondents the lower the utilization level. The finding is consistent with Adeogun (2008). They established a significant relationship between constraints and adoption of technology.

Table 8: Relationship between constraint to agro-meteorological services utilisation and utilization of agro-meteorological services

\begin{tabular}{ll}
\hline Variable & r value \\
\hline Constraint & $-0.324^{*}$ \\
\hline
\end{tabular}

${ }^{*}$ Significant at $p<0.05$

\section{Conclusion and Recommendations}

Seasonal rainfall prediction and information on crop stages performance were the mostly available and accessed agro-meteorological services. However, the extent of use of these services was generally low due to untimely information made available to the farmers by the agency. Utilisation of agrometeorological services therefore, should foster encouragement of participation that engenders involvement of local stakeholders and prompt monitoring activities that guarantee timely delivery of agro-meteorological information to farmers.

\section{References}

Adebayo, A. A, Onu, J.I, Adebayo, E. F and Anyanwu, S. O (2012). Farmers's awareness vulnerability and adaptation to climate change in Adamawa State Nigeria. British Journal of Arts and Social Sciences.. 9 (11),pp 45-61

Adebisi-Adelani, A.O (2013). Farmers Perception of the Effect of Climate Change on the production of Citrus and Tomatoes in Nigeria. An Ph.D Thesis in the 
Creative commons User License: CC BY-NC-ND

Abstracted by: EBSCOhost, Electronic Journals Service (EJS), Google Scholar, Directory of Open Access Journals (DOAJ), Journal Seek, Scientific Commons,

Food and Agricultural Organization (FAO), CABI and Scopus

\author{
Journal of Agricultural Extension \\ Vol. 21 (1) February, 2017 \\ ISSN(e): 24086851; ISSN(Print); 1119944X \\ http://journal.aesonnigeria.org \\ http://www.ajol.info/index.php/iae \\ Email: editorinchief@aesonnigeria.org
}

Department of Agricultural Extension and Rural Development, University of lbadan, Ibadan. Pp 1-123

Adeogun, S.O. (2008). Adoption of cocoa improve technologies among cocoa farmers in selected states of Nigeria. Ph.D thesis, Department of Agricultural Extension and Rural Development, University of Ibadan, Nigeria, pp. 1-191.

Agbongiarhuoyi, A. E, Abdulkarim, I. F, Fawole, O. P., Obatolu, B. O., Famuyiwa, B. S. and Oloyede, A. A ( 2013). Analysis of Farmers' Adaptation Strategies to Climate Change in Cocoa Production in Kwara State. Journal of Agricultural Extension Vol. 17(1) pp10-22

Agricultural Projects Monitoring and Evaluation Unit (1997). Evaluation of the Effectiveness of Training and Visit Extension System in Nigeria: A research report. National Agricultural Extension and Liaison Services (NAERLS), Ahmadu Bello University, Zaria, pp 89-122

Akinbile, L.A., (2010). Climate change and its implications for sustainable development in Nigeria. Essay in the Department of Agricultural Extension and Rural Development, University of Ibadan, Nigeria. 3pp.

Ann, O., Ndubisi, E.L., and Wilfred, U..(2013); Risk Management and Challenges of Climate Change in Nigeria. Journal of Human Ecology. 41(3): pp 221-235.

Anselm A. Enete and Taofeeq A. Amusa (2010). Challenges of Agricultural Adaptation to Climate Change in Nigeria: a Synthesis from the Literature. Field Actions Science Reports Journal of Field Actions 4: pp9-11

Arimi, K. (2015). Factors Affecting Rice Farmers' Technology Adoption in Ekiti and Ogun State. PhD thesis in Department of Agricultural Extension and Rural Development, University of Ibadan.

Asenso-Okyere, K. and Davis, K. (2009). Knowledge and innovation for agricultural development. International Food Policy Research Institute (IFPRI), Policy Brief 11 www.ifpri.org/bp/bp0011.asp. Accessed 9 February 2016.

Ekong, E.E., (2003). Rural Development in Nigeria. An Introduction to Rural Sociology. Ibadan: Jumak publishers Ltd. Pp.56.

European Commission DG ENV (2009) Climate change to reduce crop yields and increase child malnutrition. Bristol.

Food and Agricultural Organisation (FAO) (2008). Hunger on the Rise. Food and Agriculture Organisation. Retrieved August 7, 2015 fromhttp://www.fao.org/newsroom/EN/news/

http://www.thisdaylive.com/index.php/2016/08/08/11 Accessed 30 September 2016

International Fund for Agricultural Development (IFAD) (2007). Rural Poverty in Nigeria: Agriculture in the Federal Republic of Nigeria. International Fund 
Creative commons User License: CC BY-NC-ND

Abstracted by: EBSCOhost, Electronic Journals Service (EJS), Google Scholar, Directory of Open Access Journals (DOAJ),

Journal Seek, Scientific Commons,

Food and Agricultural Organization (FAO), CABI and Scopus
Journal of Agricultural Extension

Vol. 21 (1) February, 2017

ISSN(e): 24086851; ISSN(Print); 1119944X

http://journal.aesonnigeria.org

http://www.ajol.info/index.php/jae

Email: editorinchief@aesonnigeria.org

for Agricultural Development. Retrieved August 7, 2015 from http://www.ruralpovertyportal.org/web/guest.

Intergovernmental Panel on Climate Change (IPCC) (2007). Summary for policymakers. In: Climate Change 2007: Impacts, Adaptation and Vulnerability. Contribution of Working Group II to the Fourth Assessment Report of the Intergovernmental Panel on Climate Change, M.L. Parry, O.F. Canziani, J.P. Palutikof, P.J. van der Linden and C.E. Hanson, Eds., Cambridge University Press, Cambridge, UK, 7-22.

Intergovernmental Panel on Climate Change (IPCC) (2012). Climate change Impact Adaptability and Vulnerability. McCarthy, J.J (ed). Contribution of working Group to the Third Assessment Report of IPCC, Cambridge.Cambridge University Press.

Khanal, R.C. (2009). Climate change and organic agriculture. The Journal of Agriculture and Environment. 10, 100-110.

Maddison, D. (2007). The Perception of adaptation to climate change in Africa. The world Bank Development Research Group Sustainable Rural and Urban Development Team. Policy Research Working Paper 4308.

Medugu, N. I (2009) Nigeria: Climate Change - A Threat to the Country's Development. Retrieved August 7, 2015 from http://www.allafrica.com/nigeria/

Nigeria Meteorological Agency (NIMET) (2012). Agro-meteorological Bulletin No.35, Dekad 2, December (11-20) 2012 pp 1-2??

Nwalieji, H. U and Onwabuya, E. A. (2012). Adaptation practices to climate change among rice farmers in Anambra State, Nigeria. Journal of Agricultural Extension. 16 (1) pp 38-44

Nwanebo, C (2012). Factors associated with Sweet PotatoProduction among Rural Farmers in Imo State. Masters Project in the Department of Agricultural Extension and Rural Development, University of Ibadan. Pp1-78

Oladeji, J.O (2011). Farmers' Perception of Agricultural Advertisements in Nigerian News Papers in Ibadan Municipality, Oyo State, Nigeria. Journal of Media and Communication Studies. 3 (3), pp 97-100

Oladije-Taiwo, F.B. (2015). Prevalence of Occupation related illness and workday loss among citrus and pineapple farmers in southwestern Agricultural Zones, in Nigeria. An Ph.D Thesis in the Department of Agricultural Extension and Rural Development, University of Ibadan, Ibadan. Pp 1-200

Onyedgula, C.B (2015). Climate Change Adaptation Strategies of Rice Farmers in Nigeria. An Ph.D Thesis in the Department of Agricultural Extension and Rural Development, University of Ibadan, Ibadan. Pp 1-127 
Creative commons User License: CC BY-NC-ND

Abstracted by: EBSCOhost, Electronic Journals Service (EJS), Google Scholar, Directory of Open Access Journals (DOAJ), Journal Seek, Scientific Commons,

Food and Agricultural Organization (FAO), CABI and Scopus
Journal of Agricultural Extension

Vol. 21 (1) February, 2017

ISSN(e): 24086851; ISSN(Print); 1119944X

http://journal.aesonnigeria.org

http://www.ajol.info/index.php/jae

Email: editorinchief@aesonnigeria.org

Roudier, P., Muller, B., d’Aquino, P., Roncoli, C., Soumaré, M. A., Batté, L. \& Sultan, B. (2014). The role of climate forecasts in smallholder agriculture: Lessons from participatory research in two communities in Senegal. I, 2, 42-55.

Tella, M.O (2016). Livelihood Analysis and Coping Strategies of Rural Women to Climate Change IN North-western Nigeria. An Ph.D Thesis in the Department of Agricultural Extension and Rural Development, University of Ibadan, Ibadan. Pp 1-112

Van der Zaag, P. (2010). Viewpoint - Water variability, soil nutrient heterogeneity and market volatility - Why sub-Saharan Africa's Green Revolution will be location-specific and knowledge-intensive. www.water-alternatives.org. Sub-Sahara Africa's Green Revolution I3 (1): 154-160 